\title{
The Canadian oil sands development: Management of land, air and water resources
}

\author{
By Cesar A. Poveda*
}

\begin{abstract}
The Canadian oil sands -the third largest proven reserves of oil after Saudi Arabia and Venezuelaare located in Northern Alberta, Canada; these deposits of unconventional oil are an attractive investment for oil \& gas developers and governments not only because of the size of the reserves but also the geopolitical stability of the region. Nevertheless, the development of the projects and current operations are facing opposition and struggling with a negative campaign around the world due in part to misinformation of the facts, lack of knowledge of the process throughout the projects life cycle, and years of stakeholder mismanagement. Indisputably, the development of the projects carries a series of impacts (environmental, social, economic, and health); developers and operators may dispute the intensity of the impacts but not the existence of them. The manuscript discusses the impacts on land, water and air resources based on indicators included in sustainability reports presented by oil sands developing and operating organizations. These reported statistics give a broader understanding of the current state of the Canadian oil sands and their development. The aim of the manuscript is to present these statistics four most common environmental impacts from oil sands development: greenhouse gas emissions, land use, water use, and tailing ponds.
\end{abstract}

Keywords: sustainability, oil \& gas, oil sands, energy consumption.

\section{Introduction: A Brief History}

One of the earliest documented accounts of the oil sands deposits dates back nearly 300 years when in 1719 a Cree named Wa-Pa-Su brought a sample to Henry Kelsey, manager of the Hudson's Bay Company (HBC) at York Factory [Kelly, 2009]. Since, the need for meeting the demands of oil consumption has drastically increased -particularly after the industrial revolutionand precipitated the exploration and exploitation of alternatives to conventional oil; therefore, the third largest deposit after the convention oil in Saudi Arabia and heavy oil in Venezuela has become of regional, national, and international interest.

The deposits of oil sands are encountered in the province of Alberta and Saskatchewan, Canada. Underlining 142,200 square kilometres $\left(\mathrm{km}^{2}\right)$ the areas of Athabasca, Cold Lake and Peace River in northern Alberta contains 170.4 billion barrels of recoverable oil using current available technology and given certain economic conditions to make the exploitation feasible. If those conditions are met and new technology for extraction and processing is developed, there is potential for recovering 315 billion barrels ${ }^{1}$ of oil in the oil sands (Alberta Energy, 2015a; Canadian Association of Petroleum Producers, 2015a).

Using barrels as metric unit, about $80 \%$ of oil sands are recoverable using insitu processes and $20 \%$ recoverable through surface mining (Alberta Energy, 2015b). The recovery process can done using two types of processes: surface mining and in-situ. About 3 per cent of the oil sands area can be recovered using surface mining technology while the other 97 per cent of the oil sands is too deep to be mined making necessary the use and development of in-situ

\footnotetext{
11 Barrel equals to 0.158987 cubic meter
} 
recovery techniques (e.g., steam-assisted gravity drainage [SAGD], cyclic steam stimulation [CSS], vapour recovery extraction [VAPEX], cold heavy oil production with sand [CHOPS]) (Alberta Energy, 2015a).

Since Alberta's first oil sands mine opened in 1967 by the Great Canadian Oil Sands Company, now called Suncor Energy (Alberta Energy Regulator, 2015), the exploration and exploitation of the resource has exponentially increased with forecasted production indicating levels of over 587 thousand $\mathrm{m}^{3}$ (3.7 million bbls) per day by 2021 (Energy Resources Conservation Board, 2011) and 5.2 million barrels per day by 2030 (Canadian Energy Research Institute, 2014). Such rapid development in recent years has caught the attention of stakeholders due to the various environmental, social, economic, health, and other impacts the projects carry throughout their life cycles (Poveda \& Lipsett, 2013; Honarvar, Rozhon, Millington, Walden, \& Murillo, 2011a,b; Gosselin, Hrudey, Naeth, Plourde, Therrien, Van Der Kraak, \& Xu, 2010). For the development and assessment of impacts of the oil sands projects, developers, researchers, governmental organizations, and other stakeholders cannot isolate the surface mining and in-situ processes since other activities may have equal or greater effects on the overall impact of the projects. Activities associated with development and operation of the oil sands include but not limited to provisional and permanent housing and buildings, roads, oil transportation and storage, upgrading and refining, reclamation, and capture and storage of greenhouse gasses (GHGs) such as $\mathrm{CO}_{2}$.

Alberta Energy (2012c) reports the mining operations have disturbed 715 square kilometres of boreal forest as of January 2013 and $66 \%$ of the total oil sands area has been leased to developing companies for extraction distributed in each oil sands area as follow: $44 \%$ of Peace River, $74 \%$ of Athabasca, and $55 \%$ of Cold Lake. Oil sands' surface mining operations and in-situ recovery processes continue supporting Canada's total oil production which represented 56\% in 2012 and it is expected to remain growing yearly (National Energy Board, 2015). Surface mining operations represented 51\% (889,000 barrels per day) of Alberta's oil sands production in 2011 while 49\% $(854,000)$ came from in-situ operated sites (Energy Resources Conservation Board, 2012).

Oil sands' stakeholders face certain level of complexity. While there are undisputable negative impacts, the exploitation of the natural resource also carries economic benefits for those same stakeholders. Among others, existing and new projects will generate over $\$ 2,484$ billion $^{2}$ (2013 Canadian dollars), total GDP impacts of all oil sands investment re-investment and operating revenues is estimated to be $\$ 3,865$ billion (2013 Canadian dollars) for Canada, oil sands related total Canadian employment (direct, indirect and induced) is expected to peak at 802,000 jobs in 2028 which is up from current level (2014) of 514,000 jobs in 2014 while oil sands related direct employment in Alberta is expected to peak at 256,000 jobs in 2014 which is up from current level (2014) of 146,000 jobs. Oil sands related taxes directly to the Canadian Federal Government will total $\$ 574$ billion (2013 Canadian dollars) while takes (excluding royalties) directed to the Province of Alberta will total $\$ 302$ billion (2013 Canadian dollars). Forecasted oil sands royalties will grow from $\$ 4.4$ billion (2013 Canadian dollars) in 2013 to $\$ 18.2$ billion (2013 Canadian dollars) by 2023 with cumulative total of royalties collected by the Alberta Government exceeding \$ 600 billion (2013 Canadian dollars) over the next 25 year (2013 Canadian dollars), and for every direct job (1) generated in the Alberta oil sands, 1 additional job is generated by indirect association and 1.5 jobs induced association, in Canada (Canadian Energy Research Institute, 2014).

One can conclude the inevitable development of the oil sands based on factors such as forecasted data (level of investment and economic impacts at different levels), percentage of areas already leased, world's dependency on oil, and Canada's own economic growth. Without undermining the tangible economic benefits of the oil sands, the data presented in the following

2 Currency used throughout the manuscript refers to 2013 Canadian dollars. 
sections focused on one aspect of the development; the environmental performance of a selected group of oil sands developers. The analysis uses as starting point the definition of sustainability as the balance of economic, social and environmental needs (Poveda \& Lipsett, 2014) to then focus on the specific analysis of environmental performance related to three resources (land, air, and water) to demonstrate the path in which the development of the oil sands resources is currently on and providing measurable indicators to re-think if such path meets our vision for sustainability.

\section{Analysis Methodology of Collection and Classification of Data in Sustainability Reports}

The Canadian Association of Petroleum Producers (2015a) indicates the four most common environmental impacts from oil sands development are greenhouse gas emissions, land use, water use, and tailing ponds. Therefore, oil sands developers and operators realized the need for transparency in reporting sustainability performance to their internal and external stakeholders.

It has become an industry practice for oil sands developers to prepare and present a yearly sustainability report in which environmental, social and economic performance are typically discussed. Each organization independently presents a number of indicators based on internal and external stakeholders' expectations. Nevertheless, communalities are found in these reports and are used to analyse the current path the oil sands development is on. Those communalities are found in broader areas (e.g., land, water, air) of performance as developers must meet minimum legal requirements. Additionally, oil sands developers are not required to measure and/or report on specific common sustainable development indicators (SDIs) with the aim of benchmarking the performance of detailed aspects of their processes neither there is a tool currently implemented industry wide to do so. However, Poveda and Lipsett (2014) have developed the Wa-Pa-Su project sustainability rating system targeting this existing gap. The analysis is based on reports from six oil sands developers and/or operators using surface mining and in-situ technology for the exploitation of the resources. The organizations included are: Suncor Energy, Cenovus Energy Inc., Canadian Natural Resources Limited (CNRL), ConocoPhillips Co., Shell Canada, and Syncrude Canada Ltd.

\subsection{The Land Resources}

Alberta Environmental and Sustainable Resource Development (2015) reports the disturbance of $767 \mathrm{~km}^{2}$ by oil sands mining operations ( $\sim 0.2$ per cent of Alberta's boreal forest) and $77 \mathrm{~km}^{2}$ is under active reclamation as of December 31, 2012. In comparison, land disturbance using in-situ recovery processes is 1 to 15 per cent of a similar sized mining operation and produces no tailing ponds. In 2009, new definitions in the reclamation process were introduced with aim of better tracking the level of land disturbance and reclamation process. Moreover, the land use can be tracked as cleared, disturbed, ready for reclamation, soils placed, temporary reclaimed, permanent reclaimed, and certified reclaimed (Alberta Environmental and Sustainable Resource Development, 2015).

The reclamation process starts with pre-disturbance and reclamation planning to continue with tree harvest, overburden removal, oil sands mining, backfilling, recontouring, revegetation, monitoring, and finalized with certification. Before closure plans developed by mining projects developers are approved these must indicate how disturbed areas will be reclaimed. Additionally, a reclamation security (i.e., bond) must be provided as guarantee that mining operators will go thought with the reclamation process. In reclamation security for the oil sands industry, the government held over $\$ 1$ billion $^{1}$ as of June 30, 2013. The stringent reclamation process currently in place requires monitoring once the reclamation is complete since establishing a successful 
ecosystem may take over 15 years. The reclamation certificate is issued only once the reclaimed land meets the objectives of equivalent land capacity. In 2008, the first successful reclamation process was completed (Alberta Energy, 2015a), the Government of Alberta issued the land reclamation certificate to Syncrude Canada Ltd for the 104 ha parcel of land known as Gateway Hill (Government of Alberta, 2015; Canadian Association of Petroleum Producers, 2015b).

Cenovus Energy set annual performance target which in 2013 resulted in more than 2,000 wells under active reclamation and 126 reclamation certificates issued by the Province of Alberta (Cenovus Energy Inc., 2013). In reference to reclamation certificates submitted, CNRL reports 334 sites achieved full reclamation certification in 2013 totalizing 1971 hectares (ha) of land certified between 2010 and 2013; the completed progressive reclamation work shows 233 ha reclaimed since 2009, including 53 ha reclaimed prior to project start-up and first production [21]. On the other hand, ConocoPhillips Co. shows zero reclamation certificated received in 2011 which is the latest performance indicators available in its website portal (ConocoPhillips Co., 2014).

Shell Canada reports permanent and temporary reclamation for two projects: Muskeg River Mine and Jackpine Mine. The number of permanent reclaimed hectares in the Muskeg River Mine project fluctuates from 111 to 202 in the past 5 years with 158 in 2013 while the Jackpine Mine project does not report any progress in that area. On the other hand, only the Jackpine Mine project report few hectares for temporary reclamation in the past four years with only 57.1 ha in 2013 (Shell Canada, 2013). Additionally, the total active footprint -including mine and plant sizefor Shell Canada projects adds up to 13,459.70 ha in 2013 (Shell Canada, 2013) while Suncor Energy has disturbed 21,303 ha of land through mining operation since the beginning of production in 1967 (Suncor Energy, 2013). As of the end of 2012, Suncor Energy has reclaimed 1,542 ha and targeted a 100 per cent increase in land area reclaimed by 2015, as compared to 2007 (Suncor Energy, 2013).

In 2013, disturbed land used for mine or plant purposes and total active footprint -mine and plant site footprint- of Syncrude Canada Ltd. projects are 19,552 and 28,120 ha respectively; those figures represent an increment of about 14 per cent since 2009 (Syncrude Canada Ltd., 2013). In relation to temporary and permanent land reclaimed, Syncrude Canada Ltd reports 668 ha for temporary reclamation in 2013 which is down from 690 ha from the previous year while permanent land reclaimed went from 3,316 ha in 2012 to 3,403 ha in 2013 (Syncrude Canada Ltd., 2013).

\subsection{The Water Resource}

ESRD reports water used recycling levels between 80 to 95 per cent in the oil sands projects industry wide; producing one barrel of oil requires for the oil sands to use 2.5 barrels of fresh water in the surface mining process and 0.5 barrels in in-situ operations (Alberta Environmental and Sustainable Resource Development, 2015). In details, to produce one barrel of oil the mining process uses between 2 to 4 barrels of fresh water plus 8 to 10 barrels of recycled water to produced one barrel of oil while the in-situ process uses 0.5 barrels of fresh water plus 2.5 barrels of non-potable and recycled water.

The fresh water used in the oil sands projects mostly comes from the Athabasca River; therefore, there are strict limits on how much water can be extracted. Currently, less than three per cent of the average annual river flow is allocated for current and approved oil sands mines but the actual water use is less than one percent of the average annual flow. In-situ projects commonly use deep salty or brackish water instead of fresh water; however, fresh water used in the process usually comes from groundwater sources (Alberta Environmental and Sustainable Resource Development, 2015). The total amount of fresh surface water used by all oil sands mining operations in 2013 was 182.25 million $\mathrm{m}^{3}$ while the total amount of groundwater and river 
water used by all in-situ operators was 25.79 million $\mathrm{m}^{3}$ and 4.44 million $\mathrm{m}^{3}$ by all upgrader operators.

Although the production of oil from the oil sands has increased, the levels of fresh water use by mature oil sands mining operations remains similar to those in the $1980 \mathrm{~s}$ and $90 \mathrm{~s}$. The provincial regulatory system and the Athabasca River Water Management Framework set mandatory limits on withdrawals and wastewater releases. Other frameworks have been developed to protect the water quality of regional aquifers and the lower Athabasca River, the groundwater management framework is set to develop a regional groundwater monitoring network and sets interim regional groundwater quality triggers for key indicators, and the surface water quality management framework was developed to protect aquatic life and other surface water quality uses (Alberta Environmental and Sustainable Resource Development, 2015)

Cenovus Energy Inc. (2013) reports the use of fresh ad saline water in its Corporate Sustainability Report; fresh water use has increased from 3,874 thousand barrels (Mbbls) in 2009 to $19,997 \mathrm{Mbbls}$ in 2013 while saline water consumption in 2009 was of 25,218 Mbbls increasing to 64,451 in 2013 . Intensity indicates the impact on the resources to produce a unit of the final product; therefore, water use intensity is interpreted as the number of barrels of water used to produce a barrel of oil equivalent (BOE). Cenovus Energy Inc shows an improvement in saline water use as the intensity went from 0.78 in 2009 to 0.46 in 2013. On the other hand, the fresh water intensity is increasing as the indicator went from 0.12 in 2009 to 0.27 in 2013.

CNRL reports its performance in the annual Stewardship Report to Stakeholders [21]. Levels of fresh water withdrawal which in 2010 were at $20,845,454 \mathrm{~m}^{3}$ increased to $22,823,208 \mathrm{~m}^{3}$ in 2013 while brackish, non-potable water use went from $117,369 \mathrm{~m}^{3}$ to $859,299 \mathrm{~m}^{3}$ in the same time period. Although CNRL does not report the water use intensity the organization claims water recycle rates of 94.9 in the Pelican Lake polymerflood operations and 99.8 per cent in the Nipisi light oil waterflood operations.

ConocoPhillips Co. (2014) reports sustainability performance in a website portal called MetricsOil sands; however, the latest report dates back to 2011. Three indicators to highlight in the time period of 2007 to 2011: 1) fresh groundwater use went from $426,560 \mathrm{~m}^{3}$ to $856,113 \mathrm{~m}^{3}, 2$ ) produced water disposed increased from $279,704 \mathrm{~m}^{3}$ to $486,311 \mathrm{~m}^{3}$, and 3) water use intensity shows levels of 0.66 bbls water/BOE in the latest year.

Shell Canada in the 2013 Oil Sands Performance Report classifies the water use in three areas of operations: Scotford upgrader, mine, and in-situ (Shell Canada, 2013). While the water use of all areas of operations went from 103.1 million $\mathrm{m}^{3}$ in 2009 to 148.1 million $\mathrm{m}^{3}$ in 2013 , water use intensity presents a different outlook. In the Scotford upgrader the fresh water intensity has fluctuated between 0.5 and 0.4 while mine water use intensity decreased from 2 in 2009 to 1.2 in 2013 and in-situ fresh water intensity was at 1.4 in the past year.

Suncor Energy reports for oil sands mining operations to have consumed $2.06 \mathrm{~m}^{3}$ of river water and groundwater to produce $1 \mathrm{~m}^{3}$ of oil in 2012 which represents water consumption reduction of 104 per cent since 2007 (Suncor Energy, 2013). Finally, Syncrude Canada Ltd.'s sustainability report does not provide much of a positive outlook since the fresh water withdrawal levels present minimal fluctuation but the fresh water use intensity is definitely increasing. Fresh water use intensity (barrel water/barrel production SCO [synthetic crude oil]) went from 1.97 in 2010 to 2.37 in 2013 and fresh water use intensity (barrel water/barrel bitumen) when from 1.7 to 2.09 in the same time period (Syncrude Canada Ltd., 2013).

\subsection{Tailing Ponds}

Oil sands in its natural form cannot be directly used by refineries to produce usable fuels (e.g., gasoline and diesel); therefore, the mixture of sand, clay or other minerals, water and bitumen known as oil sands must be mixed with hot water and diluent (naphthanic, parafanic) to 
separate the bitumen from the sand. As a result, water, clay, bitumen, organic compounds and solvents become tailings that must be contain in ponds as provincial law restrict the release of water that has been in contact with bitumen into regional water bodies. The use of tailing ponds allows the settlement of fines and coarse sands and storage of water for reuse. As seepages are potential risks, the tailings ponds are built with groundwater monitoring systems and groundwater collection systems to facilitate capturing seepage and returning it to the pounds.

Currently, there is about 77 square kilometres of oil sands ponds water in Alberta (Alberta Environmental and Sustainable Resource Development, 2015). The operations of the oil sands projects generates an average of 100,000 barrel a day of oil sands mine which creates enough volume of tailings to fill over 8 Olympic-size swimming pools (Alberta Environmental and Sustainable Resource Development, 2015). As a result of increasing oil production, Alberta Energy Resources Conservation Board issued Directive 074 in February of 2009 included tougher regulations for managing tailings. Oil sands operators must not only reduce tailings but also provide target dates for closure and reclamation of ponds. In order to prevent birds from landing on the ponds, the management of tailings ponds requires bird deterrence systems in place meeting the government's approval requirements.

Land disturbance occurs because of different the processes including the creation of tailing ponds; therefore, these areas must go under the reclamation process. Industry developers and operators have planted more than 12 million tree seedling towards reclamation efforts (Alberta Energy, 2015a) including the 6 million trees planted by Suncor Energy of which 900,000 trees were planted just in 2012 (Suncor Energy, 2013). Wildlife and biodiversity is another aspect of the reclamation process of land used for tailing ponds, mining or any other operation in the development of the oil sands projects. For large-scale industrial operations Environmental Impact Assessments (EIAs) are mandatory; oil sands developers and operators are required to create management plans with the aim of minimizing the impacts on wildlife and other biodiversity as law and regulations in place are to protect the environment; the Alberta's government is required to monitor and verify the industry follow through the implementation of the plans (Alberta Environmental and Sustainable Resource Development, 2015). In their annual sustainability reports, developers and operators include the different efforts made towards protecting wildlife and biodiversity; the Shell Buffalo Hills Conversation Rand is a good example of the commitment towards sustainability. The ranch is conservation property located one hour southeast of Calgary that includes 1,671 hectares of pristine, native grasslands, and an additional 715 hectares of tame hay lands and it is an area for the breeding, migration or wintering of 159 bird species that use both native prairie and the boreal forest of Alberta (Shell Canada, 2013).

Finally, as one of the most challenging areas of the oil sands development, the tailing ponds are the focus for research and development among stakeholders including government, scientists, developers, and operators. Efforts are made in different fronts: tailings performance criteria, management technologies, and initiatives to accelerate the reclamation of areas used for tailings ponds (Alberta Environmental and Sustainable Resource Development, 2015; Cenovus Energy Inc., 2013; Canadian Natural Resources Limited, 2013; ConocoPhillips Co., 2014; Shell Canada, 2013; Suncor Energy, 2013; Syncrude Canada Ltd., 2013).

\subsection{The Air Resource}

Alberta Environmental Protection and Enhancement Act (EPEA) underlines the Alberta's ambient air quality objectives and guidelines. The Air Quality Health Index (AQHI) indicates the air quality of the surroundings; it is calculated based on the risks of a combination of pollutants known to harm human health. Those pollutants include ozone at ground level, particulate matter $\left(\mathrm{PM}_{2.5} / \mathrm{PM}_{10}\right)$ and nitrogen dioxide $\left(\mathrm{NO}_{2}\right)$ (Environment Canada, 2015). The $\mathrm{AQHI}$ is measured using a scale of 1 to $10+$ in which higher numbers indicate higher health risk: 
low (1 to 3 ), moderate (4 to 6 ), high (7 to 10 , and very high (above 10). To control the releases of substances and pollutants to the atmosphere from industrial activities monitoring stations are located throughout the oil sands area. Currently, the air quality in the sands region count with 15 active stations operated by the Wood Buffalo Environmental Association (WBEA) which monitors the air quality 24 hours a day and 365 days a year across the region. Additionally, the industry possesses another 70 passive stations and the WBEA has portable monitoring stations for their use as required (Alberta Environmental and Sustainable Resource Development, 2015).

Cenovus Energy Inc. and Syncrude Canada Ltd. present a decreasing path of NOx emissions while the other organizations included in the analysis shows fluctuations in the rate of emissions or do not incorporate such information in their sustainability report. The performance of Cenovus Energy Inc. in the past 5 years regarding NOx emissions and NOx intensity presents a decrease from 18,020 to 8,971 tonnes and 1 to 0.41 tonnes/thousand $\mathrm{m}^{3} \mathrm{OE}$ (oil equivalent) respectively (Cenovus Energy Inc., 2013) while Syncrude Canada Ltd. reports NOx emissions of 26.11 thousand tonnes in 2013 which represents a decrease of over 15\% compare to the performance reported for the year of 2010 (Syncrude Canada Ltd., 2013). On the other hand, CNRL reports a significant decrease in NOx emissions from 2010 to 2011; however, NOx emissions are on the rise since 2011. From 2011 to 2012 the NOx emissions increased over 24.7 per cent and the 5,395 tonnes in 2013 represents an increase of over 9.4 per cent compared to the previous year (Canadian Natural Resources Limited, 2013). Similarly, ConocoPhillips Co.'s performance is not improving in this area; NOx emitted in the past 5 years has increased from 0.065 kilotonnes (kT) in 2007 to $0.22 \mathrm{kT}$ in 2011 which represent an increase of over 238 per cent (ConocoPhillips Co., 2014). Shell Canada and Suncor Energy do not include NOx or SOx performance indicators in their sustainability reports; however, $\mathrm{CO}_{2}$ emissions and intensity performance are tracked and Suncor Energy forecasts its performance through 2017.

$\mathrm{SO}_{2}$ emissions performance shows fluctuations in those four organizations that include the indicators in their sustainability report (i.e., CNRL, Cenovus Energy Inc. ConocoPhillips Co., Syncrude Canada Ltd.) which makes difficult to drop conclusions. Cenovus Energy Inc.'s $\mathrm{SO}_{2}$ emissions and intensity range in the past 5 years from 1,671 to 2,428 tonnes and 0.08 to 0.1 tonnes/thousand $\mathrm{m}^{3} \mathrm{OE}$ respectively (Cenovus Energy Inc., 2013) while CNRL reports values oscillate from 1,988 to 4,060 tonnes of SOx emissions between 2010 and 2013 (Canadian Natural Resources Limited, 2013). Similarly, ConocoPhillips Co.'s emissions of SOx fluctuates from 0.0015 to $0.36 \mathrm{kT}$ in the period between 2007 and 2011 [22] and Syncrude Canada Ltd. reports $\mathrm{SO}_{2}$ emissions between 63.13 and 81.47 thousand tonnes per year in the period between 2009 to 2013 (Syncrude Canada Ltd., 2013).

Additional indicators are found in individual reports. Cenovus Energy Inc. includes indicators related to steam to oil ratio (SOR), total gas flared, and total gas vented (Cenovus Energy Inc., 2013) while ConocoPhillips Co includes gas flared and vented CNRL only reports on total gas flared (Canadian Natural Resources Limited, 2013; ConocoPhillips Co., 2014) and Shell Canada mainly focus on indicators related to $\mathrm{CO}_{2}$ emissions reporting direct, indirect and intensity for insitu, Scotford upgrader, and Jackpine and Muskeg River mine operations. Other indicators are particulate matter (PM), volatile organic compounds (VOCs) included in the sustainability reports of Sycrude Canada Ltd. and ConocoPhillips Co. and benzene emitted from glycol dehydrators and natural gas fuel usage are indicators reported only by ConocoPhillips Co (ConocoPhillips Co., 2014; Syncrude Canada Ltd., 2013).

\subsection{GHG Emissions}

The main greenhouse gases are carbon dioxide $\left(\mathrm{CO}_{2}\right)$, methane $\left(\mathrm{CH}_{4}\right)$, and nitrous oxide $\left(\mathrm{NO}_{2}\right)$. By sector, the oil sands operations represent $22 \%$ within the Province of Alberta while nationwide the oil and gas industry represents 18\% (excluding oil sands) and the oil sands adds 
$5 \%$ of the GHG emissions. Therefore, Alberta's oil sands account for less than $0.15 \%$ of the world's GHG emissions (Alberta Environmental and Sustainable Resource Development, 2015).

The Province of Alberta became the first jurisdiction in North America with mandatory reduction regulations for large emitters. Those industrial facilities emitting more than 100,000 tonnes of GHG a year are required to lower emissions intensity by 12 per cent, buy carbon offsets or pay a fee. 3.9 million tonnes of offset credits were purchased in 2010 from those Alberta projects that were unable to reduce emissions. Oil sands companies have been able to reduce GHG emission per barrel of oil by an average of 39 per cent since 1990 due to investment in research and technology (Alberta Environmental and Sustainable Resource Development, 2015). Nevertheless, fuels produced from oil sands create between 5 to 15 per cent more emissions than the average crude oil processed in the United States (Alberta Environmental and Sustainable Resource Development, 2015).

By 2050, Alberta's emissions target includes 200 mega Tonnes (Mt) reduction or 50 per cent below projected business as usual and 14 per cent below 2005 levels. Those $200 \mathrm{Mt}$ are presented as follow: $24 \mathrm{Mt}$ from conservation \& energy efficiency, $139 \mathrm{Mt}$ from Carbon capture \& storage, and $37 \mathrm{Mt}$ from green energy production (Alberta Environmental and Sustainable Resource Development, 2015).

As the emissions of GHGs and oil production increase in parallel, the intensity metric gains relevance among stakeholders including industry (developers and operators), scientists and governmental organizations. Cenovus Energy Inc. presents the ideal scenario of the relation between an increase in oil production and a decrease in GHGs emissions intensity; the direct GHG emissions for the organization increased from 1,899 $\mathrm{kT} \mathrm{CO}_{2} \mathrm{E}$ in 2009 to 3,618 kT CO $2 \mathrm{E}$ in 2013 while the direct GHG emissions intensity for the same time period went from 0.37 to 0.3 tonnes $\mathrm{CO}_{2} \mathrm{E} / \mathrm{m}^{3} \mathrm{OE}$ (Cenovus Energy Inc., 2013). On the other hand, other organizations indicators show fluctuations in the past few years which makes difficult to estimate future performance. Including total direct emissions from combustion, flaring, formation $\mathrm{CO}_{2}$, and other venting and fugitive leaks from equipment the GHG emissions intensity for CNRL from 2010 to 2013 range from 0.0901 to 0.1119 tonnes $\mathrm{CO}_{2} \mathrm{E} / \mathrm{BOE}$ while direct and indirect GHG emissions have been on the rise (Canadian Natural Resources Limited, 2013). Similarly, the GHG emissions -as per Environment Canada quantification guidelines- for Syncrude Canada Ltd. operations shows an increment from 2012 to 2013 performance with a generation of 12.46 million of tonnes of GHG emissions in the latest year but there is fluctuation in the data reported for GHGs millions of tonnes in the past 5 years ranging from 11.67 to 12.87 (Syncrude Canada Ltd., 2013). Additionally, GHGs tones $\mathrm{CO}_{2} \mathrm{E}$ per barrel produced and cubic metre produced have steadily increased for the past 5 years showing 0.112 and 0.694 respectively in 2013 (Syncrude Canada Ltd., 2013).

Developing and operating organization report other indicators related to GHG and air resource performance. Energy use and energy intensity allow to broaden the understanding of the magnitude of the oil sands projects. Cenovus Energy Inc. and Syncrude Canada Ltd. report their energy consumption and intensity performance; however, the data offers two different outlooks of the industry; while the energy use for Cenovus Energy Inc. has been steadily increasing with 71.1 million of Gigajoule (GJ) consumed in 2013, Syncrude Canada Ltd. shows the opposite reporting 129,705 billion BTUs (British thermal unit) consumed in the same year. Regarding energy intensity, Cenovus Energy Inc presents constant improvement in performance for the past 5 years as the indicator shows a decrease from 7.26 to $5.98 \mathrm{GJ} / \mathrm{m}^{3} \mathrm{OE}$ while Syncrude Canada Ltd. reports an increase from 1.26 to 1.31 million BTUs per barrel in the past four years (Cenovus Energy Inc., 2013; Syncrude Canada Ltd., 2013). 


\section{Conclusions and Future Research}

Developers and operators of oil sands projects are obligated to meet minimum requirements enforced by law. The creation and evolution of regulations for the development and operation of the oil sands projects have accelerated in the past couple of decades due in part to the need for addressing stakeholders' concerns and their goals, objectives and vision for a sustainable future. While regulatory requirements are being met, the oil sands development is still facing numerous challenges adding to the complex environment in which is not enough for developers and operators to report sustainability performance, engage and work with stakeholders, and invest in research and development among several other efforts. Furthermore, if the oil sands are one of the most stringent regulated projects in North America but the public perception is still negative towards their development, it is time for questioning: 1) are the oil sands facing a communication issue?, 2) are (were) the stakeholders properly managed?, 3) are the current regulations rigorous enough, and 4) are the current regulations meeting the stakeholders' needs?

The aim of sustainability performance reporting is to address the communication and transparency issues between organizations and their internal and external stakeholders. Nevertheless, the current reporting strategies implemented by each organization does not require any standardization which becomes an obstacle from the benchmarking standpoint. It is then required the development and implementation of tools for measuring and reporting of sustainability performance considering in the design of the tools the need for all stakeholders to understand what is measured and what that means in relation to the overall performance of the organization and within the industry. Decision-making tools such as sustainability and environmental rating systems are structured to support performance assessment throughout the projects life cycle. Currently, the majority, if not all, rating systems created to date focus on buildings and residential housing construction; therefore, it is necessary to pursue the diversification of sustainability and environmental rating systems and their application in other industry context as such tools have demonstrated the transformation of the building industry while carrying diverse benefits for all stakeholders.

\section{References}

Alberta Energy. (2015). Facts and Statistics. Retrieve from http://www.energy.alberta.ca/OilSands/791.asp Alberta Energy. (2015). Resources. Retrieve from http://www.energy.alberta.ca/OilSands/1715.asp

Alberta Energy. (2015). Alberta's Leased Oilsands Area. Retrieve from http://www.energy.gov.ab.ca/LandAccess/pdfs/OSAagreeStats.pdf

Alberta Energy Regulator. (2015). Highlights in Alberta Energy Regulator. Retrieve from http://www.aer.ca/about-aer/spotlight-on/unconventional-regulatory-framework/highlights-inalbertas-energy-development

Alberta Environment and Sustainable Resource Development. (2015). Oil Sands Information Portal. Retrieve from http://osip.alberta.ca/map/

Canadian Association of Petroleum Producers. (2015). Energy \& Economy. Retrieve from http://www.capp.ca/canadaIndustry/oilSands/Energy-Economy/Pages/default.aspx

Canadian Association of Petroleum Producers. (2015). Environment. Retrieve from http://www.capp.ca/canadaIndustry/oilSands/environment/Pages/default.aspx

Canadian Association of Petroleum Producers. (2015). Land. Retrieve from http://www.capp.ca/canadaIndustry/oilSands/environment/land/Pages/default.aspx

Canadian Energy Research Institute. (2014). Canadian Economic Impacts of New and Existing Oil Sands Development in Alberta (2014-2038). Retrieve from http://www.ceri.ca/images/stories/CDN Economic Impacts of New and Existing Oil Sands D evelopment in Alberta - November 2014 - Final.pdf 
Canadian Natural Resources Limited. (2013). Stewardship report to stakeholders. Retrieve from http://www.cnrl.com/corporate-responsibility/stewardship-report/

Cenovus Energy Inc. (2013). Corporate Responsibility Report. Retrieve from http://www.cenovus.com/reports/corporate-responsibility/

ConocoPhillips Co. (2014). Metrics-Oil Sands. Retrieve from http://www.cpcsustainability.com/where-wework/oilsands/metrics-1.cfm

Energy Resources Conservation Board. (2011). Big Reserves, Big Responsibility: Developing Alberta's Oil Sands Retrieve from https://www.aer.ca/documents/newsreleases/OilSandsRegulatoryCaseStudy 201104.pdf

Energy Resources Conservation Board. (2012). ST98-2012: Alberta's Energy Reserves 2011 and Supply/Demand Outlook 2012-2021. Retrieve from http://www.strategywest.com/downloads/ERCB ST98 2012.pdf

Environment Canada. (2015). About the Air Quality Health Index. Retrieve from http://www.ec.gc.ca/casaqhi/default.asp?Lang=En\&n=065BE995-1

Gosselin, P., Hrudey. S. E., Naeth, M. A., Plourde, A., Therrien, R., Van Der Kraak, G., \& Xu, Z. (2010). The Royal Society of Canada expert panel: environmental and health impact of Canada's oil sands industry. The Royal Society of Canada: Ottawa.

Government of Alberta. (2015). Reclaiming Alberta's Oil Sands. Retrieve from http://www.environment.alberta.ca/02012.html

Honarvar, A., Rozhon, J., Millington, D., Walden, T., \& Murillo, C. A. (2011) Economic impacts of new oil sands projects in Alberta (2010-2035). Canadian Energy Research Institute,. Study No. 124.

Honarvar, A., Rozhon, J., Millington, D., Walden, T., \& Murillo, C. A. (2011). Economic impacts of staged development of oil sands projects in Alberta (2010-2035). Canadian Energy Research Institute. Study No. 125 - Section I: Calgary.

Kelly, G. (2009). The oil sands - Canada's path to clean energy?. Cochrane, AB.: Kingsley Publishing Service Inc.

National Energy Board. (2015). Estimated Production of Canadian Crude Oil and Equivalent. Retrieve from http://www.neb.gc.ca/nrg/sttstc/crdlndptrlmprdct/stt/stmtdprdctn-eng.html

Poveda, C., \& Lipsett, M. (2013). The Canadian Oil sands: environmental, economic, social, health, and other impacts. Proc. of the $6^{\text {th }}$ Int. Conf. on Sustainable Development and Planning, eds. C.A. Brebbia, WIT Press: Southampton and Boston, pp. 1-26, 2013

Poveda, C., \& Lipsett, M. (2014). An integrated approach for sustainability assessment: the Wa-Pa-Su project sustainability rating system. International Journal of Sustainable Development and World Ecology, 21(1), pp. 8598.

Shell Canada. (2013). Oil Sands Performance Report 2013. Retrieve from http://s00.staticshell.com/content/dam/shell-new/local/country/can/downloads/pdf/oil-sands/oil-sandsperformance-report-2013.pdf

Suncor Energy. (2013). Report on Sustainability 2013. Retrieve from http://www.suncor.com/en/responsible/1434.aspx

Syncrude Canada Ltd. (2013). Syncrude 2013 Sustainability Report. Retrieve from http://syncrudesustainability.com/2013/ 